\title{
Jurist-Diction
}

Volume 4 No. 1, Januari 2021

\section{Tindak Pidana Pencucian Uang dan Penipuan Arisan Online sebagai Kejahatan Asal}

\author{
Peppy Rahmawati \\ peppyrahmawati26@gmail.com \\ Universitas Airlangga
}

How to cite:

Peppy Rahmawati, 'Tindak Pidana Pencucian Uang dan Penipuan Arisan Online sebagai Kejahatan Asal' (2021) Vol. 4 No. 1 Jurist-Diction.

\section{Histori artikel:}

Submit 1 Oktober 2020; Diterima 12 November 2020; Diterbitkan 5 Januari 2021.

DOI:

10.20473/jd.v4i1.24302

p-ISSN: 2721-8392

e-ISSN: $2655-8297$

\section{Abstract}

Technological advances in society nowadays have positive and negative impacts. Technology can help people carry out their daily activities. But technology also able to lead criminal acts. One of the community activities which change along with technological advances is a Rotating Savings and Credits Associations (ROSCAs). People usually do ROSCAs by directly meeting. But currently, ROSCAs change to online. People do not need to meet directly for ROSCAs. On the other hand, many criminal acts related to ROSCAs. Fraud perpetrators take advantage of the negligence of the party's in online ROSCAs. Perpetrators will get assets as a result of fraud. The perpetrators will hide these assets so that their origin is unknown. The act of the perpetrator is a crime of money laundering. This article discusses the characteristics of the fraud of online ROSCAs as stipulated in the Indonesia Criminal Code (KUHP) and the Information and Electronic Transactions Law (UU ITE). The second discussion is about the responsibility of the perpetrators of money laundering crimes with the fraud of online ROSCASs as the original crime. The method of this thesis is doctrinal research or normative with two approaches, namely the statute approach and the case approach. Keywords: Fraud; Rotating Savings and Credits Associations; Money Laundering.

\begin{abstract}
Abstrak
Kemajuan teknologi yang terjadi dalam masyarakat membawa dampak positif dan negatif. Teknologi dapat membantu masyarakat melakukan kegiatan sehari-hari. Namun teknologi juga dapat mengakibatkan terjadinya tindak pidana. Salah satu kegiatan masyarakat yang berubah seiring dengan kemajuan teknologi adalah arisan. Masyarakat biasanya melakukan arisan dengan bertemu secara langsung. Namun saat ini berkembang arisan dengan metode online. Masyarakat tidak perlu bertatap muka secara langsung saat melakukan arisan. Di sisi lain tindak pidana penipuan yang berkaitan dengan arisan online juga banyak terjadi. Pelaku memanfaatkan kelengahan para pihak dalam arisan online. Pelaku akan memperoleh keuntungan berupa aset-aset dari tindak pidana penipuan. Pelaku akan menyembunyikan aset tersebut agar tidak diketahui asal-usulnya. Perbuatan pelaku tersebut adalah tindak pidana pencucian uang. Artikel ini membahas mengenai karakteristik penipuan arisan online sebagaimana diatur dalam KUHP dan Undang-Undang Informasi dan Transaksi Elektronik. Pembahasan selanjutnya yaitu mengenai pertanggungjawaban pelaku tindak pidana pencucian uang dengan penipuan arisan online sebagai kejahatan
\end{abstract}


asal. Penulisan artikel ini menggunakan metode doctrinal research atau normatif dengan dua pendekatan yaitu pendekatan perundangundangan (statute approach) dan pendekatan kasus (case approach).. Kata Kunci: Sistem Penyelesaian Sengketa; World Trade Organization; Appellate Body; Right to Access to Justice; Pemblokiran.

Copyright (c) 2021 Universitas Airlangga

\section{Pendahuluan}

Saat ini masyarakat telah mengalami kemajuan dalam bidang teknologi. Kemajuan teknologi juga berdampak pada kegiatan masyarakat sehari-hari. Seluruh kegiatan masyarakat sehari-hari saat ini didukung dengan kemajuan teknologi. Salah satu kegiatan masyarakat yang terdampak adalah kegiatan arisan. Dahulu masyarakat menyelenggarakan arisan hanya dengan orang-orang terdekat atau orang yang tinggal di lingkungan yang sama. Namun saat ini dalam sebuah arisan dimungkinkan terdiri dari peserta yang berasal dari daerah yang berbeda. Kecanggihan teknologi dapat menyatukan orang-orang dari berbagai tempat berbeda untuk mengikuti suatu arisan yang sama.

Kemajuan teknologi tidak hanya memberikan dampak positif berupa terbantunya masyarakat dalam menjalankan kegiatan sehari-hari. Namun kemajuan teknologi tersebut juga mendatangkan dampak negatif. Seringkali tindak pidana yang terjadi saat ini tidak terlepas dari penggunaan teknologi. Tidak terkecuali kegiatan arisan online. Salah satu tindak pidana yang terjadi karena arisan online adalah penipuan.

Sebuah kasus menyita perhatian pada 2017 yang terjadi di Martapura. Seorang perempuan muda bekerja sama dengan suaminya membuat arisan online fiktif. Perempuan muda tersebut bertindak sebagai owner arisan yang diberi nama Iray Kasfy dan mendapatkan banyak peserta. Owner memberikan penawaran yang sangat menarik melalui blackberry messenger kepada calon peserta seperti pencairan arisan yang cepat dan tepat waktu, memberikan bonus, cashback serta hadiah. Selain itu owner juga menawarkan kepada beberapa peserta untuk menjadi reseller yang bertugas mencari peserta baru. Namun setelah peserta mencapai ratusan dan uang peserta arisan terkumpul miliaran rupiah, owner melarikan diri tanpa memenuhi janji yang ia berikan. Fakta yang terungkap bahwa owner tidak 
pernah membuat arisan sejak awal. Ia hanya mengaku mengelola arisan online agar banyak orang yang tertarik untuk mengikuti arisan. Akibat perbuatannya, majelis hakim dalam putusan Nomor 349/Pid.Sus/2017/PN MTP menjatuhi pidana terhadap terdakawa yaitu penjara selama 4 tahun.

Kasus serupa juga terjadi di Surabaya pada 2015 oleh seorang perempuan yang berperan sebagai bandar arisan online. Bandar tersebut membuat arisan online dengan media grup facebook. Arisan yang didirikannya dengan peserta ratusan berhenti di tengah jalan, karena uang peserta yang berjumlah miliaran rupiah ia gunakan untuk mengembangkan bisnisnya yang lain. Akibatnya para peserta tidak mendapatkan hak nya kembali. Berdasarkan putusan Nomor 842/PID.SUS/2015/ PN.SBY hakim menjatuhkan pidana penjara selama 2 tahun 6 bulan dan denda sebesar Rp 500.000,00 dengan ketentuan apabila denda tidak dibayarkan diganti dengan kurungan 1 bulan. Putusan hakim tersebut berdasarkan dakwaan tunggal jaksa penuntut umum yaitu Pasal 28 ayat (1) juncto Pasal 45 ayat (1) UU ITE.

Tindak pidana penipuan diatur di dalam maupun di luar KUHP. Tindak pidana penipuan diatur dalam Pasal 378 hingga 395 KUHP. Sedangkan dalam peraturan perundang-undangan di luar KUHP penipuan diatur dalam Undang-Undang No 19 Tahun 2016 tentang Perubahan Atas Undang-Undang No 11 Tahun 2008 tentang Informasi dan Transaksi Elektronik selanjutnya disebut UU ITE. Dua peraturan perundang-undangan berbeda mengatur hal yang sama menimbulkan konsekuensi tersendiri. Kedua peraturan perundang-undangan tersebut memiliki karakteristik berbeda dalam mengatur tentang penipuan. Namun seringkali para penegak hukum menerapkan peraturan perundang-undangan berbeda untuk kasus yang sama.

Pelaku tindak pidana penipuan arisan online memperoleh keuntungan materiil berupa aset atau harta kekayaan. Agar tidak diketahui kejahatannya maka pelaku akan berusaha untuk menyembunyikan aset tersebut. Pelaku yang menyembunyikan aset hasil tindak pidana juga melakukan tindak pidana lainnya. Tindak pidana penipuan arisan online berlanjut menjadi tindak pidana pencucian uang.

Tindak pidana penipuan merupakan tindak pidana yang sering terjadi di masyarakat dan umumnya tidak memberikan dampak yang besar. Namun apabila 
tindak pidana penipuan berlanjut menjadi tindak pidana pencucian uang, tentu saja dampak yang ditimbulkan akan berbeda. Tindak pidana pencucian uang merupakan kejahatan terorganisasi dan sistematis yang dapat menyebabkan terganggunya stabilitas perekonomian suatu negara.

Tindak pidana penipuan arisan online tidak pernah diproses menjadi tindak pidana pencucian uang mesikipun banyak tindak pidana penipuan arisan online yang merugikan masyarakat dalam jumlah besar dan pelaku berpotensi melakukan tindak pidana pencuciang uang. Sehingga banyak korban tindak pidana penipuan arisan online yang tidak mendapatkan aset nya kembali. Artikel ini akan membahas bagaimana karakteristik tindak pidana penipuan arisan online dan bagaimana pertanggungjawaban pidana pelaku tindak pidana penipuan arisan online yang berimplikasi pada tindak pidana pencucian uang.

\section{Terminologi Arisan Online}

Arisan merupakan suatu kegiatan yang tidak asing lagi bagi masyarakat Indonesia. Arisan adalah kegiatan yang dilakukan sekelompok orang dengan mengadakan perkumpulan dalam kurun waktu atau periode tertentu dengan mengumpulkan sejumlah uang atau barang kemudian dilakukan pengundian. ${ }^{1}$ Pengundian dilakukan untuk menentukan peserta yang berhak mendapat uang arisan. Peserta yang memperoleh undian akan berbeda tiap periode pengundian. Pengundian biasanya dilakukan tiap bulan atau minggu sesuai dengan kesepakatan.

Arisan merupakan suatu istilah untuk menyederhakan suatu regulasi keuangan yang disebut Rotating Savings and Credit Associations (ROSCAs) yaitu kegiatan yang dilakukan sekelompok orang dengan mengadakan perkumpulan dalam kurun waktu atau periode tertentu dengan mengumpulkan sejumlah uang atau barang kemudian dilakukan pengundian. ${ }^{2}$ Pengundian tersebut bertujuan untuk

\footnotetext{
1 Yupri Maryuni, 'Pelaksanaan Arisan Di Kelurahan Muara Lembu Kecamatan Singingi Kabupaten Kuantan Singingi Ditinjau Menurut Hukum Islam’ (Universitas Islam Negeri Sultan Syarif Kasim Riau 2015).

2 Bayu Kharisma and others, 'The Economics of Rotating Savings and Credit Associations (ROSCAs) and Poverty in Indonesia' (2020) 16 Jurnal Economia.[100].
} 
menentukan peserta pemenang yang berhak memperoleh arisan. Arisan tersebut merupakan arisan yang dilakukan secara konvensional. Saat ini ada berbagai macam jenis arisan diantaranya yaitu arisan biasa, arisan gugur, dan arisan online.

Arisan online merupakan arisan yang dilakukan melalui media online. Berbeda dari jenis arisan lainnya, arisan online menggunakan teknologi daring berupa smartphone atau komputer dan internet. Pihak yang terlibat dalam arisan online adalah owner sebagai pengelola dan para peserta. Sistem pengundian arisan online biasanya menggunakan sistem gugur. Arisan online tidak memerlukan pertemuan antara pengelola dan anggotanya secara langsung. Semua transaksi dilakukan secara online. ${ }^{3}$

Tidak adanya pertemuan secara langsung diantara pengelola dan peserta memberikan peluang untuk terjadinya tindak pidana. Tindak pidana yang sering terjadi berkaitan dengan arisan online adalah tindak pidana penipuan. Terdapat dua peraturan perundang-undangan yang mengatur tindak pidana penipuan arisan online.

\section{Penipuan Arisan yang Diatur dalam KUHP}

Tindak pidana penipuan yang diatur dalam KUHP terdapat dalam Pasal 378 yaitu:

"Barang siapa dengan maksud menguntungkan dirinya atau orang lain dengan melanggar hukum, baik dengan perbuatan-perbuatan tipu muslihat maupun dengan rangkaian kebohongan, membujuk orang lain, supaya menyerahkan suatu barang atau supaya membuat utang atau menghapuskan piutang, dihukum karena penipuan dengan hukuman penjara selama-lamanya empat tahun".

Pasal 378 KUHP memiliki unsur-unsur sebagai berikut:

a. Unsur subyektif : dengan maksud (met he oogmerk) untuk menguntungkan diri sendiri atau orang lain secara melawan hukum.

b. Unsur obyektif:

1. Barang siapa.

Barang siapa dalam hal ini ditujukan untuk pelaku.

\footnotetext{
3 Ida Ayu Sukihana and others, 'Tanggung Jawab Ketua Dalam Penyelenggaraan Arisan Ditinjau Dari Hukum Perjanjian’ (2016) 4 Kertha Semaya : Journal Ilmu Hukum.[3].
} 
2. Menggerakkan orang lain agar menyerahkan suatu benda, mengadakan suatu perikatan utang, dan meniadakan suatu piutang.

Menyerahkan suatu benda dalam rumusan Pasal 378 KUHP tersebut berarti suatu tindakan yang dilakukan seseorang untuk memisahkan suatu benda dari penguasaan pemiliknya dengan cara dan keadaan apapun. Menurut Hoge Raad penyerahan merupakan unsur konstitutif dari tindak pidana penipuan sehingga barang tersebut tidak harus langsung diserahkan kepada pelaku namun juga dapat diserahkan kepada perantara yang telah diperintah oleh pelaku. ${ }^{4}$

3. Dengan memakai:

a. Nama palsu. Terdapat beberapa perbuatan yang termasuk memakai nama palsu yaitu:

1. Menggunakan nama orang lain dalam melakukan perbuatannya; ${ }^{5}$

2. Seseorang yang menggunakan suatu nama yang tidak diketahui pasti keberadaannya; ${ }^{6}$

3. Seseorang menggunakan nama yang tidak biasanya ia gunakan di masyarakat meskipun ia menggunakan namanya sendiri. ${ }^{7}$

b. Kedudukan palsu.

Hoge Raad dalam arrestnya 27 Mei 1893 menyatakan bahwa perbuatan menggunakan kedudukan palsu adalah bersikap secara menipu terhadap orang ketiga, misalnya sebagai seorang kuasa, seorang agen, seorang wali, seorang kurator ataupun yang dimaksud untuk memperoleh kepercayaan sebagai seorang pedagang atau seorang pejabat. ${ }^{8}$

c. Tipu muslihat.

Tipu muslihat merupakan perbuatan yang membuat orang lain percaya dan perbuatan tersebut terlihat benar. ${ }^{9}$

d. Rangkaian kata-kata bohong.

Rangkaian kata-kata bohong menurut Prof. Satochid Kartanegara adalah serangkaian kata-kata yang saling berhubungan dan membenarkan satu sama lain padahal dapat diketahui kata-kata tersebut tidak benar. ${ }^{10}$

\footnotetext{
Adami Chazawi, Kejahatan Terhadap Harta Benda (Bayumedia 2004).

ibid.[124].

ibid.[125].

ibid.

ibid.[126].

ibid.

10 Theo Lamintang P.A.F Lamintang, Delik-Delik Khusus: Kejahatan Terhadap Harta
} Kekayaan (Sinar Grafika 2009). 


\section{Penipuan Arisan yang diatur dalam UU ITE}

UU ITE tidak menyebut secara langsung mengenai tindak pidana penipuan, namun terdapat satu pasal yang dapat mengakomodir tindak pidana penipuan dengan media online. Peraturan tersebut terdapat dalam Pasal 28 ayat (1) UU ITE yaitu: "Setiap orang dengan sengaja dan tanpa hak menyebarkan berita bohong dan menyesatkan yang mengakibatkan kerugian konsumen dalam Transaksi Elektronik." Ancaman pidananya terdapat pada Pasal 45 A ayat (1) UU ITE yaitu pidana penjara paling lama 6 (enam) tahun dan/atau denda paling banyak RP 1.000.000.000,00 (satu miliar rupiah).

Unsur-unsur yang terdapat dalam Pasal 28 ayat (1) UU ITE yaitu:

1. Unsur subyektif :

a. Setiap orang.

Setiap orang yang didefinisikan lebih lanjut dalam Pasal 1 angka 21 sebagai orang perseorangan atau manusia dan badan usaha. UU ITE telah mengenal badan usaha sebagai subjek hukum selain orang.

b. Dengan sengaja tanpa hak.

Dengan sengaja dan tanpa hak artinya pelaku memang berkehendak untuk melakukan perbuatannya. Tanpa hak termasuk dalam unsur melawan hukum, artinya orang tersebut melakukan perbuatan yang dilarang oleh hukum atau orang tersebut tidak memiliki kewenangan untuk melakukan perubuatan tersebut. Unsur ini merupakan unsur yang mutlak terkandung dalam rumusan delik meskipun tidak dituliskan secara tersurat.

2. Unsur obyektif :

a. Perbuatan menyebarkan berita bohong dan menyesatkan.

Unsur ini mengandung perbuatan pelaku membagikan berita yang tidak benar. Berita bohong atau yang sekarang sering disebut sebagai hoax adalah berita yang tidak benar atau berita mengenai suatu keadaan yang palsu. Dengan kata lain berita hoax adalah suatu informasi yang 
kredibilitasnya tidak dapat dipertanggungjawabkan. ${ }^{11}$

b. Timbulnya suatu akibat yaitu kerugian konsumen dalam melakukan transaksi elektronik.

Unsur ini menunjukkan akibat dari berita bohong dan menyesatkan yaitu ruginya konsumen yang melakukan transaksi secara elektronik. Kerugian konsumen yang terjadi dapat beragam jenisnya.

\section{Perbedaan Pengaturan Penipuan dalam KUHP dan UU ITE}

Tindak pidana penipuan diatur dalam KUHP dan UU ITE. Terdapat beberapa perbedaan yang diatur dalam kedua peraturan perundang-undangan tersebut. Berdasarkan uraian di atas terdapat beberapa perbedaan yang terdapat dalam KUHP dan UU ITE yaitu:

1. KUHP dan UU ITE dalam mengatur tindak pidana penipuan memiliki perbedaan dalam hal alat bukti. Alat bukti yang berlaku dalam KUHP diatur dalam KUHAP tanpa alat bukti elektronik. Berdasarkan Pasal 184 KUHAP alat bukti yang sah adalah keterangan saksi, keterangan ahli, surat, petunjuk, dan keterangan terdakwa. Sedangkan UU ITE memperluas alat bukti yaitu berlakunya alat bukti elektronik yang merupakan perluasan dari alat bukti surat yang telah diatur oleh Pasal 5 ayat (4) KUHAP. Berdasarkan Pasal 5 ayat (1) UU ITE, informasi elektronik dan/atau dokumen elektronik dan hasil cetaknya merupakan alat bukti yang sah sesuai dengan hukum acara pidana di Indonesia. Alat bukti elektronik merupakan perluasan alat bukti di luar KUHAP. Apabila berdasarkan UU ITE maka alat bukti juga ditambah alat bukti elektronik. ${ }^{12}$

2. KUHP memiliki unsur menguntungkan diri sendiri atau orang lain sedangkan dalam UU ITE hal terpenting adalah akibat dari penipuan yang berupa kerugian konsumen telah tercapai tanpa harus mengetahui apakah terdapat pihak tertentu yang diuntungkan.

3. KUHP mengatur secara rinci dalam Pasal 378 mengenai cara penipuan terjadi seperti dengan nama palsu, martabat atau kedudukan palsu, serta rangkaian kebohongan dan tipu muslihat. Sedangkan dalam UU ITE tidak diatur hal yang sama. Namun mengingat pada dasarnya KUHP dan UU ITE mangatur tindak pidana yang sama yaitu penipuan dengan medianya saja yang berbeda, penipuan dalam UU ITE tidak menutup kemungkinan pelaku juga akan menggunakan cara yang serupa.

\footnotetext{
${ }^{11}$ Dedi Rianto Rahadi, 'Perilaku Pengguna Dan Informasi Hoax Di Media Sosial' (2017) 5 Jurnal Manajemen Dan Kewirausahaan.[58].

12 Nur Laili Isma and Arima Komiyatun, 'Kekuatan Pembuktian Alat Bukti Informasi Elektronik Serta Hasil Cetaknya Dalam Pembuktian Tindak Pidana' (2014) 1 Jurnal Penelitian Hukum. [110].
} 
4. Perbedaan sanksi juga terdapat dalam KUHP dan UU ITE. Pada UU ITE terdapat sanksi tambahan berupa denda sebagaimana diatur dalam Pasal 45 A ayat (1) UU ITE yaitu pidana penjara paling lama 6 (enam) tahun dan/atau denda paling banyak RP 1.000.000.000,00 (satu miliar rupiah). Sedangkan dalam Pasal 378 KUHP pelaku tindak pidana penipuan hanya dengan pidana penjara selama 4 (empat) tahun.

\section{Tindak Pidana Pencucian Uang Dengan Penipuan Arisan Online Sebagai Kejahatan Asal}

Pelaku tindak pidana penipuan akan berusaha agar kejahatannya tidak diketahui orang lain. Pelaku akan berusaha menyembunyikan aset hasil dari penipuan. Perbuatan pelaku dalam menyembunyikan aset tersebut juga nerupakan tindak pidana yaitu tindak pidana pencucian uang. Tindak pidana pencucian uang tidak dapat berdiri sendiri. Untuk dapat terjadinya pencucian uang maka harus diawali dengan tindak pidana lainnya sebagai predicate crime atau tindak pidana asal. Tindak pidana pencucian uang tiatur dalam UU No 8 Tahun 2010 Tentang Pencegahan dan Pemberantasan Tindak Pidana Pencucian Uang. UU PTPPU tersebut secara tersurat mengatur mengenai predicate crime termasuk penipuan yang diatur dalam pasal 2 ayat (1) huruf r UU PTPPU.

Dalam tindak pidana pencucian uang terdapat langkah-langkah atau tipologi hingga terjadi pencucian uang. Tipologi tindak pidana pencucian uang terdiri dari 3 langkah yaitu:

\section{Placement}

Placement atau penempatan adalah proses awal yang akan dilakukan pelaku terhadap harta benda yang dihasilkan dari kejahatan. Salah satu contoh terjadinya placement yaitu seorang pengedar narkotika menggunakan uang hasil penjualan obat terlarang untuk membeli kendaraan pribadi. Uang tersebut telah beralih kepada penjual kendaraan sehingga uang tersebut menjadi sah dan tidak diketahui asalnya. Uang yang semula didapatkan secara ilegal kemudian masuk kedalam sistem perekonomian yang sah menjadikan uang tersebut juga 
legal digunakan. ${ }^{13}$

2. Layering

Layering atau pemisahan yaitu upaya pelaku untuk mencampurkan uang hasil kejahatan dengan uang yang sah. Pelaku akan melakukan transaksi yang rumit bahkan hingga memindahkan uang tersebut ke beberapa yurisdiksi atau perusahaan yang berbeda demi menghilangkan jejak asal-usul uang tersebut. Sehingga uang tersebut dapat digabungkan kembali dalam sistem perbankan yang sah. ${ }^{14}$

3. Integration

Tahap terakhir yaitu integration atau penggabungan yaitu uang yang semula hasil dari perbuatan ilegal masuk kedalam sistem perekonomian menjadi uang yang sah. Dalam tahap ini sudah sangat sulit untuk menemukan jejak dari mana uang tersebut berasal. Agar pencucian uang dapat mudah terdeteksi maka seharusnya penegak hukum melakukan upaya pencarian bukti sejak tahapan placement atau penempatan. Penting sekali bagi penyedia jasa keuangan seperti bank untuk menjalankan prinsip know your custommer (KYC) atau the due dilligence custommer (DDC). ${ }^{15}$

Pusat Pelaporan dan Analisis Transaksi Keuangan (PPATK) mengklasifikasikan duajenis pelaku dalam tindak pidana pencucian uang yaituaktif dan pasif. Tindakpidana pencucian uang aktif dan pasif memiliki perbedaan pada perbuatan pelaku. Tindak pidana pencucian uang aktif sebagaimana diatur dalam Pasal 3 dan 4 UU PTPPU, pelaku akan berperan secara langsung dalam menyamarkan atau menyembunyikan aset hasil kejahatan. Tindak pidana pencucian uang pasif pada Pasal 5 UU PTPPU pelaku tidak berperan secara langsung dalam menyamarkan atau menyembunyikan aset hasil kejahatan, melainkan hanya menerima manfaat kekayaan dari tindak pidana serta turut berperan dalam menyembunyikan kekayaan tersebut. ${ }^{16}$

${ }^{13}$ Mohd Yazid bin Zul; Kepli and Maruf Adeniyi Nasir, 'Money Laundering: Analysis on the Placement Methods' (2016) 11 International Journal of Business, Economics and Law.[9].

14 ibid.

15 ibid.

${ }^{16}$ Ade Riyanda and Prasetia Putra, 'Analisis Ekonomi Terhadap Hukum Tindak Pidana Pencucian Uang’ (2003) 4 Lex Renaissance.[310]. 
Perbuatan aktif pelaku tindak pidana pencucian uang diatur dalam Pasal 3 UU PTPPU yaitu menempatkan, mentransfer, mengalihkan, membelanjakan, membayarkan, menghibahkan, menitipkan, membawa ke luar negeri, mengubah bentuk, menukarkan dengan mata uang atau surat berharga atau perbuatan lain atas harta kekayaan yang diketahuinya atau patut diduganya merupakan hasil tindak pidana. Tindak pidana pencucian uang aktif juga diatur dalam Pasal 4 UU PTPPU yaitu perbuatan menyembunyikan atau menyamarkan asal-usul, sumber, lokasi, peruntukan, pengalihan hak-hak atau kepemilikan yang sebenarnya atas harta kekayaan yang diketahuinya atau patut diduganya merupakan hasil tindak pidana.

Tindak pidana pencucian uang pasif sebagaimana diatur dalam Pasal 5 UU PTPPU menunjukkan bahwa perbuatan pelaku menerima atau menguasai penempatan, pentransferan, pembayaran, hibah, sumbangan, penitipan, penukaran, atau menggunakan harta kekayaan yang diketahuinya atau patut diduganya merupakan hasil tindak pidana. Perbuatan tersebut jelas berbeda dengan pelaku aktif pada tindak pidana pencucian uang. Pelaku pasif hanya berperan menerima atau mendiami tempat pelaku aktif menyimpan harta kekayaan hasil kejahatan.

Tindak pidana penipuan dapat berimplikasi pada tindak pidana pencucian uang apabila pelaku tidak hanya melakukan penipuan sebagaimana diatur dalam Pasal 378 KUHP dan Pasal 28 ayat (1) juncto Pasal 45 A ayat (1) UU ITE. Namun pelaku juga berusaha untuk menghilangkan jejak dari mana uang tersebut berasal. Dalam penipuan arisan online terdapat beberapa jenis pelaku yang akan secara langsung berperan dalam menyembunyikan harta kekayaan hasil menipu pesertanya dan secara tidak langsung terlibat.

Pelaku penipuan arisan online yang langsung berperan dalam menghilangkan jejak harta kekayaan adalah owner arisan. Owner lah yang memegang semua kendali jalannya arisan online. Namun dalam mengupayakan menghilangkan jejak, owner akan meminta bantuan orang lain agar lebih tersamarkan. Owner akan meminta bantuan orang lain untuk meminjamkan rekeningnya. Hal ini bertujuan untuk mengelabuhi penyidik dalam mencari aliran dana. Orang yang meminjamkan rekening tersebut termasuk pelaku yang berperan secara tidak 
langsung apabila ia dapat menduga bahwa harta yang dititipkan kepadanya merupakan hasil tindak pidana.

Berdasarkan jenis pelaku di atas maka tindak pidana pencucian uang yang dapat terjadi dengan penipuan arisan online sebagai predicate crime adalah tindak pidana pencucian uang aktif dan pasif. Tindak pidana pencucian uang aktif dapat dilakukan oleh owner berdasarkan Pasal 3 UU PTPPU. Owner secara langsung menempatkan, mentransfer, mengalihkan, membelanjakan, membayarkan, menghibahkan harta kekayaan hasil perbuatan menipunya.

Tindak pidana pencucian uang pasif dapat dilakukan oleh orang yang dipilih owner sebagai penerima atau penguasa penempatan, penerima dana transfer, pembayaran, hibah, sumbangan, penitipan, penukaran, atau ikut menggunakan harta kekayaan hasil tindak kejahatan dan ia mengetahuinya. Tindak pidana pencucian uang pasif tersebut sesuai dengan Pasal 5 UU PTPPU.

Tindak pidana penipuan arisan online merupakan tindak pidana yang sering terjadi dan menimbulkan kerugian masyarakat namun sangat jarang diproses ke ranah tindak pidana pencucian uang. Terdapat beberapa faktor yang menyebabkan sedikitnya tindak pidana pencucian uang dengan penipuan arisan online sebagai tindak pidana asal.

Banyak kasus penipuan arisan online yang dilaporkan ke kepolisian, namun peyidik sulit menemukan bukti yang konkret. Seringkali pelaku tidak melakukan tahapan tipologi pencucian uang seperti placement dan layering. Apalagi jika jumlah transaksi yang terjadi hanya sedikit. ${ }^{17}$ Selain itu arisan online yang bukan merupakan penyedia jasa keuangan yang legal sehingga tidak mudah ditelusuri dan tidak meninggalkan jejak transaksi yang jelas. Meskipun arisan online diselenggarakan oleh penyedia jasa keuangan yang legal tidak menjamin transaksinya akan mudah dideteksi. Hal ini berkaitan dengan ketentuan Pasal 23 ayat (1) UU PTPPU yang mengatur penyedia jasa keuangan wajib kepada PPATK atas transaksi paling sedikit

\footnotetext{
${ }^{17}$ Kompas, 'UU TPPU Masih Jarang Digunakan' (Kompas, 2012) <https://nasional.kompas. com/read/2012/09/13/15445653/UU.TPPU.Masih.Jarang.Digunakan 13 September 2012> accessed 24 June 2020.
} 
Rp 500.000.000,00 (lima ratus juta rupiah). Sedangkan arisan online biasanya tidak melibatkan transaksi yang besar.

Kurangnya keberanian penyidik untuk melakukan proses penyelidikan tindak pidana pencucian uang juga menjadi salah satu faktor sedikitnya kasus penipuan arisan online yang dibawa ke tindak pidana pencucian uang. Berdasarkan penelitian yang dilakukan terhadap Kepolisian Daerah Jawa Timur, penyidik kerap kali mendapatkan ancaman ketika melakukan penyelidikan kasus tindak pidana pencucian uang. Selain itu penyidik tidak memiliki kemampuan yang mumpuni untuk mencari alat bukti pencucian uang atas transaksi yang dilakukan secara online menjadi kesulitan tersendiri sehingga penipuan arisan online tidak dibawa ke tindak pidana pencucian uang. ${ }^{18}$

\section{Pertanggungjawaban Pidana Pelaku Tindak Pidana Pencucian Uang dengan Penipuan Arisan Online sebagai Kejahatan Asal}

Pelaku tindak pidana sudah seharusnya mempertanggungjawabkan perbuatannya. Namun tidak semua pelaku tindak pidana dapat dikenai pertanggungjawaban. Terdapat beberapa faktor yang harus dipertimbangkan untuk menjatuhi pertanggungjawaban terhadap seseorang. Hal ini berkaitan dengan teori dualistis yaitu teori yang memisahkan antara tindak pidana dan kesalahan. Dalam teori dualistis mengatur bahwa terbuktinya seseorang melakukan tindak pidana belum tentu membuktikan adanya pertanggungjawaban pidana. Hakim wajib membuktikan perbuatan melawan hukum sebagai tindak pidana, kemudian dapat dipertimbangkan mengenai pertangungjawaban pidana.

Pertanggungjawaban pidana tidak terlepas dari asas "tiada pidana tanpa kesalahan”. Seseorang yang perbuatannya telah memenuhi unsur delik peraturan perundang-undangan, belum memenuhi syarat untuk dijatuhi pidana. Melainkan

\footnotetext{
${ }^{18}$ Lili Sari Aggraini Purba and Khairunnisa Harahap, 'Kendala Dalam Penyidikan Terhadap Tindak Pidana Pencucian Uang (Studi Di Kepolisian Daerah Jawa Timur)’ (2019) 53 Journal of Chemical Information and Modeling.[13].
} 
harus dipertimbangkan juga apakah pelaku memiliki kesalahan. ${ }^{19}$ Kesalahan terdiri dari beberapa unsur yaitu terjadinya tindak pidana, pelaku telah dewasa atau mampu bertanggungjawab, terdapat kesengajaan atau kealpaan, dan tidak ada alasan pembenar dan pemaaf. ${ }^{20}$

Tindak pidana pencucian uang yang memiliki dua jenis pelaku yaitu aktif dan pasif. Namun kedua jenis pelaku tersebut dapat diklasifikasikan lagi berdasarkan subyek hukumnya. Berdasarkan Pasal 1 angka 9 UU PTPPU subyek hukum atau yang disebut setiap orang adalah orang perorangan dan korporasi. Korporasi merupakan perkumpulan orang atau harta kekayaan baik yang berbadan hukum maupun tidak. Tindak pidana pencucian uang didahului oleh predicate crime. Dalam hal ini penipuan arisan online merupakan predicate crime. Penipuan arisan online diatur dalam Pasal 378 KUHP dan 28 ayat (1) juncto Pasal 45 A ayat (1) UU ITE. Kedua pasal tersebut mengatur bahwa subyek hukum adalah orang perseorangan dan korporasi. Apabila pelaku adalah korporasi maka pertanggungjawaban pidana tetap sama seperti apabila pelakunya adalah orang perseorangan yaitu harus melihat unsur kemampuan bertanggung jawab, adanya kesalahan, dan tidak ada alasan pembenar dalam korporasi.

Kasus tindak pidana pencucian uang dengan penipuan arisan online sebagai kejahatan asal, dapat dibuktikan terlebih dahulu adanya tindak pidana asal yaitu penipuan kemudian diproses menjadi tindak pidana pencucian uang. Tindak pidana penipuan arisan online diatur dalam dua peraturan perundang-undangan yaitu KUHP dan UU ITE.

Pasal 28 ayat (1) UU ITE memiliki karakteristik yang lebih khusus dibanding Pasal 378 KUHP dalam konteks pemidanaan dalam penipuan arisan online UU ITE adalah lex specialis dari KUHP. Pasal 28 ayat (1) UU ITE telah memenuhi beberapa prinsip dalam asas lex specialis derogat legi generalis yaitu:

1. Ketentuan yang terdapat dalam aturan hukum umum tetap berlaku, kecuali yang diatur khusus dalam aturan hukum khusus tersebut.

\footnotetext{
19 Sudarto, Hukum Dan Perkembangan Masyarakat (Sinar Baru 1983).

20 Adami Chazawi, Pelajaran Hukum Pidana Bagian 1, Stelsel Pidana, Teori-Teori Pemidanaan \& Batas Berlakunya Hukum Pidana (PT Raja Grafindo 2002).
} 
2. Ketentuan lex specialis harus sederajat dengan ketentuan lex generalis.

3. Ketentuan lex specialis harus berada dalam lingkungan hukum yang sama dengan lex generalis. ${ }^{21}$

Kasus-kasus penipuan arisan online yang terjadi di Indonesia diputus dengan peraturan perundang-undangan yang berbeda oleh majelis hakim. Hakim memiliki wewenang dalam memberikan pertimbangan dan penilian terhadap kasus yang diadili. Namun berdasarkan kekhususan karakteristik UU ITE diatas, maka tindak pidana arisan online lebih tepat diputus menggunakan Undang-Undang No 19 Tahun 2016 tentang Perubahan Atas Undang-Undang No 11 Tahun 2008 tentang Informasi dan Transaksi Elektronik.

Tindak pidana penipuan arisan online yang telah terbukti dapat diproses menjadi tindak pidana pencucian uang. Terdapat 3 Pasal yang dapat dikenakan untuk pelaku sesuai dengan perbuatannya. Apabila pelaku berperan aktif dalam melakukan pencucian uang, maka pelaku dapat dipidana berdasarkan Pasal 3 atau 4 Undang-Undang No 8 Tahun 2010 tentang Pencegahan dan Pemberantasan Tindak Pidana Pencucian Uang. Sedangkan pelaku yang tidak berperan secara langsung melakukan pencucian uang maka dapat dipidana berdasarkan Pasal 5 UndangUndang No 8 Tahun 2010 tentang Pencegahan dan Pemberantasan Tindak Pidana Pencucian Uang.

\section{Kesimpulan}

Penipuan arisan online sama halnya dengan penipuan pada umumnya atau disebut penipuan konvensional. Perbedaannya hanya terletak pada media yang digunakan. Penipuan arisan online menggunakan media elektronik sedangkan penipuan konvensional tidak melibatkan media elektronik. Terdapat dua peraturan perundang-undangan yang dapat digunakan dalam penipuan arisan online. Pasal 378 KUHP dan Pasal 28 ayat (1) juncto Pasal 45 A ayat (1) Undang-Undang No 19

\footnotetext{
21 AA Oka Mahendra, 'Harmonisasi Peraturan Perundang-Undangan' (2010) < http://ditjenpp.kemenkumham.go.id/htn-dan-puu/421-harmonisasi-peraturan-perundang-undangan.html > accessed 8 July 2020.
} 
Tahun 2016 tentang Perubahan Atas Undang-Undang No 11 Tahun 2008 tentang Informasi dan Transaksi Elektronik. Kedua peraturan perundang-undangan tersebut memiliki karakteristik masing-masing dalam menjatuhkan pidana. Sehingga Pasal 28 ayat (1) juncto Pasal 45 A ayat (1) Undang-Undang No 19 Tahun 2016 tentang Perubahan Atas Undang-Undang No 11 Tahun 2008 tentang Informasi dan Transaksi Elektronik adalah yang paling tepat digunakan dalam kasus tindak pidana penipuan arisan online.

Pelaku penipuan arisan online sangat jarang dipidana dengan tindak pidana pencucian uang. Namun bukan berarti tidak mungkin apabila perbuatan pelaku menimbulkan kerugian yang besar bagi masyarakat. Termasuk kasus arisan Iray Kasfy ini yang menimbulkan kerugian hingga miliaran rupiah bagi ratusan masyarakat yang menjadi pesertanya. Adapun peraturan perundang-undangan yang dapat digunakan untuk kasus pencucian uang adalah Undang-Undang No 8 Tahun 2010 tentang Pencegahan dan Pemberantasan Tindak Pidana Pencucian Uang.

\section{Daftar Bacaan}

\section{Buku}

Adami Chazawi, Kejahatan Terhadap Harta Benda (Bayumedia 2004).

Adami Chazawi, Pelajaran Hukum Pidana Bagian 1, Stelsel Pidana, Teori-Teori Pemidanaan \& Batas Berlakunya Hukum Pidana (PT Raja Grafindo 2002).

Sudarto, Hukum Dan Perkembangan Masyarakat (Sinar Baru 1983).

Theo Lamintang P.A.F Lamintang, Delik-Delik Khusus: Kejahatan Terhadap Harta Kekayaan (Sinar Grafika 2009).

\section{Jurnal}

Ade Riyanda and Prasetia Putra, 'Analisis Ekonomi Terhadap Hukum Tindak Pidana Pencucian Uang’ (2003) 4 Lex Renaissance.

Bayu Kharisma and others, 'The Economics of Rotating Savings and Credit Associations (ROSCAs) and Poverty in Indonesia' (2020) 16 Jurnal Economia.

Dedi Rianto Rahadi, 'Perilaku Pengguna Dan Informasi Hoax Di Media Sosial' 
(2017) 5 Jurnal Manajemen Dan Kewirausahaan.

Ida Ayu Sukihana and others, 'Tanggung Jawab Ketua Dalam Penyelenggaraan Arisan Ditinjau Dari Hukum Perjanjian' (2016) 4 Kertha Semaya : Journal Ilmu Hukum.

Lili Sari Aggraini Purba and Khairunnisa Harahap, 'Kendala Dalam Penyidikan Terhadap Tindak Pidana Pencucian Uang (Studi Di Kepolisian Daerah Jawa Timur)' (2019) 53 Journal of Chemical Information and Modeling.

Mohd Yazid bin Zul; Kepli and Maruf Adeniyi Nasir, 'Money Laundering: Analysis on the Placement Methods' (2016) 11 International Journal of Business, Economics and Law.

Nur Laili Isma and Arima Komiyatun, 'Kekuatan Pembuktian Alat Bukti Informasi Elektronik Serta Hasil Cetaknya Dalam Pembuktian Tindak Pidana' (2014) 1 Jurnal Penelitian Hukum.

\section{Laman}

Kompas, 'UU TPPU Masih Jarang Digunakan' (Kompas, 2012) <https:// nasional.kompas.com/read/2012/09/13/15445653/UU.TPPU.Masih.Jarang. Digunakan 13 September 2012>.

\section{Perundang-undangan}

Undang-Undang No 1 Tahun 1946 tentang Pengaturan Hukum Pidana.

Undang-Undang No 73 Tahun 1958 tentang Menyatakan Berlakunya UndangUndang No 1 Tahun 1946 Republik Indonesia tentang Peraturan Hukum Pidana Untuk Seluruh Wilayah Republik Indonesia dan Mengubah Kitab Undang-Undang Hukum Pidana.

Undang-Undang No 11 Tahun 2008 tentang Informasi dan Transaksi Elektronik.

Undang-Undang No 8 Tahun 2010 tentang Pencegahan dan Pemberantasan Tindak Pidana Pencucian Uang.

Undang-Undang No 19 Tahun 2016 tentang Perubahan Atas Undang-Undang No 11 Tahun 2008 tentang Informasi dan Transaksi Elektronik.

\section{Skripsi}

Yupri Maryuni, 'Pelaksanaan Arisan Di Kelurahan Muara Lembu Kecamatan Singingi Kabupaten Kuantan Singingi Ditinjau Menurut Hukum Islam' (Universitas Islam Negeri Sultan Syarif Kasim Riau 2015). 
Peppy Rahmawati: Tindak Pidana Pencucian...

--halaman ini sengaja dibiarkan kosong-- 